\title{
INVESTIGATION OF CONFIDENTIALITY AGREEMENTS IN E-COMMERCE WEBSITES VIA EYE TRACKING METHOD
}

\section{E-TİCARET SİTELERINNDEKI GIZLILIIK SÖZLEŞMELERININ GÖZ HAREKETLERINI İZLEME YÖNTEMIYYLE İNCELENMESİ}

\author{
Esra ÖZMEN ${ }^{1} \mid$ Ersin KARAMAN 2,*
}

1 Öğr. Gör., Atatürk Üniversitesi, Bilgisayar Bilimleri Araştırma ve Uygulama Merkezi, Türkiye, 0RCID: 0000-0001-6661-3473

2 Doç. Dr., Ankara Hacı Bayram Veli Üniversitesi, İIBF, Yönetim Bilișim Sistemleri Bölümü, Türkiye, 0RCID: 0000-0002-6075-2779

\section{Article Info:}

Received : October 26, 2020

Revised : December 11,2020

Accepted : December 24, 2020

\author{
Keywords: \\ e-commerce \\ Confidentiality agreements \\ Eye-tracking \\ PDPA \\ Personal data protection \\ Anahtar Kelimeler: \\ e-ticaret \\ Gizlilik sözlesmeleri \\ Göz hareketlerini izleme \\ KVKK \\ Kișisel verilerin korunması
}

DOI: $10.46238 /$ jobda. 816257

\section{ABSTRACT}

Confidentiality agreements are of great importance in Law Number 6698 and the legal regulations on e-commerce. The purpose of this experimental study is to reveal to what extent users / customers pay attention to confidentiality agreements in e-commerce processes. Within the scope of the study, data were collected via an eye tracking device from participants who carried out a real shopping process over e-commerce. The selection of the sample group was determined according to the maximum variation sampling method which is one of the purposive sampling types. 16 participants from different gender, education levels and generation groups were included in the study. Collected eye tracking data were analyzed and visualized via a software. As a result, it was found that while female participants focused on the end of sentences in the confidentiality agreement, male participants focused relatively homogeneously throughout the text. In addition, it has been found that the text part that the participants focus more on vary according to their education level. It is also concluded that the participants in the generation $\mathrm{Z}$ focus more on the parties and obligations part of the confidentiality agreements. In general, it is found that the participants focus more on the last part of the confidentiality agreements text, while they focus less on the middle part of it. According to the results, evaluations were made regarding the formats of the confidentiality agreement text.

\section{ÖZET}

Gizlilik sözleșmeleri 6698 sayılı kanun ve e-ticaret hakkında yapılan yasal düzenlemeler içinde büyük öneme sahiptir. Bu deneysel çalışmanın amacı e-ticaret süreçlerinde kullanıcıların/müşterilerin gizlilik sözleşmelerine ne ölçüde dikkat ettiklerini ortaya koymaktır. Çalıșma kapsamında e-ticaret üzerinden gerçek bir alışveriș süreci gerçekleștiren katılımcılardan göz izleme cihazı kullanılarak veri toplanmıștır. Örneklem grubunun seçimi amaçsal örnekleme türlerinden maksimum çeșitlilik örnekleme yöntemine göre yapılmıştır. Araştırmaya farklı cinsiyet, eğitim seviyeleri ve kuşak gruplarından olmak üzere 16 katılımcı dâhil edilmiștir. Toplanan göz hareketleri verileri bir yazılım yardımı ile analiz edilmiş ve görselleştirilmiştir. Sonuç olarak, gizlilik sözleşmesinde kadın katılımcılar cümle sonlarına odaklanırken erkek katılımcıların metnin genelinde nispeten homojen odaklandığı bulunmuştur. Ayrıca, katılımcıların daha çok odaklandıkları sözleșme bölümlerinin eğitim seviyesine göre değișiklik gösterdiği sonucuna ulaşılmıştır. Z kuşağındaki katılımcıların sözleşme metninin taraflar ve yükümlülükler bölümüne daha fazla odaklandıkları sonucuna da varılmıştır. Genel olarak katılımcların sözleşme metninin son bölümüne daha çok odaklandıkları, orta bölümüne ise odaklanmalarının en az olduğu görülmektedir. Sonuçlara göre gizlilik sözleșmesi metinlerinin biçimlerine yönelik değerlendirmeler yapılmıștır.

(c) 2020 JOBDA All rights reserved

\footnotetext{
*Corresponding Author.

E-mail address: ersin.karaman@hbv.edu.tr (E. Karaman)
} 


\section{1 | GİRIŞ}

Teknolojik gelişmeler ihtiyaçlarımızın boyutlarını değiştirirken, eğitim, çalışma ve hatta sosyal hayatımızda da farklılıklar oluşturmaktadır. Örneğin; eğitim, teknoloji desteği ile birlikte uzaktan eğitim platformları ile gerçekleşmektedir. Çalışma hayatımızdaki klasik belgeleme faaliyetleri ise belge yönetim sistemleri ile yürütülmektedir. Aynı zamanda sosyal hayatımızdaki arkadaşlıklarımız sosyal medya mecralarında ilerleme kaydederken, alışverişlerimiz de geleneksel işletmelerden ziyade eticaret aracılığıyla gerçekleştirilmektedir. Görüldüğü gibi teknoloji gelişimi bireylere zaman ve mekân kayması yaşatarak büyük kolaylıklar sağlamaktadır. Fakat bu kolaylıkların yanında eğitimden alışverișe bütün platformlarda "ad, soyad, öğrenci numarası, kimlik numarası ve iletişim bilgileri" gibi kişisel verilerimiz işlenmektedir. $\mathrm{Bu}$ tür verilerimizin işlendiği platformlarda gizlilik koşullarının tarafımıza beyan edilmesi zorunluluk haline gelmiştir.

6698 sayılı Kișisel Verilerin Korunması Kanunu'nda (KVKK) kişisel veri kavramı, "kimliği belirli veya belirlenebilir gerçek kişiye ilişkin her türlü bilgi" olarak tanımlanmıştır (T.C. Cumhurbaşkanlığı Mevzuat Bilgi Sistemi, 2016). 2016 yılında yürürlüğe giren KVKK ile birlikte düzenlemeler yapılmıştır. İşletmeler, özel sektörler, üniversiteler ve diğer kamu kurumları da dahil olmak üzere kişisel verinin alındığı, saklandığı, ișlendiği ve imha edildiği bütün kuruluşlara KVKK kapsamında bașta gizlilik olmak üzere birçok düzenleme ve sınırlılık getirilmiştir. Kişisel verilerin işlenmesinde; rıza gösterilmesi, şeffaflık ve dürüstlük kuralına uyulması, verinin güncel olması, açık amaçla işlenmesi, toplanma amacına uygun işlenmesi gibi ilkeler bulunmaktadır (Oğuz, 2018). Söz konusu ilkeler kişisel veri gizliliğinde eşit öneme sahiptir ve veri koruma düzenlemelerine uygunluğun temelini oluşturmaktadır (Yücedağ, 2019).

$\mathrm{Bu}$ konu alanyazında ele alınmaya başlanmış ve bilimsel çalışmalar yapılmıştır. Örneğin; kişisel verilerin korunma politikasının analizinin yapıldı $\breve{~}$ bir çalışmada, KVKK mevzuatının kabul görmesi hem vatandaşlar hem de kurumlar açısından içselleştirilmesi gerektiği aktarılmıştır. Bu içselleştirme durumu için belirli bir zaman aralığına ihtiyaç duyulduğu ve toplumun kanuna uyum sağladıkça kanunun etkinliğinin artacağı ifade edilmiştir (Kutlu \& Kahraman, 2017).

Eroğlu (2018), mahremiyet kavramı ve kişisel veriler üzerine yaptığı çalışmada dijital ortamlarla sürekli etkileşim içerisinde olan öğrencilerin dijital yaşamdaki gizlilik ve kişisel veriler konusunda algı ve farkındalık düzeylerini araştırmıştır. Çalışması kapsamında bilgi ve belge yönetimi öğrencilerinin kişisel veriler hakkında genel bir bilgi sahibi oldukları fakat kişisel verilerin net olarak tanımlanması konusunda yetersiz oldukları görülmüştür. Bunun yanı sıra katılımcıların KVKK hakkında sadece kanunu ismen bildikleri ve içeriği hakkında bir bilgi sahibi olmadıkları görülmüsstür. Ayrıca toplumun konu hakkında farkındalığının artırılması ve oluşturulan sözleşme metinlerinin anlaşlabilirliğine yönelik iyileştirme çalışmalarının yapılması önerilmiştir. Aslanyürek (2016) tarafından yapılan bir çalışmada ise internet ve sosyal medya kullanıcılarının çevrimiçi gizlilik ve güvenlik ihlalleri farkındalıklarının yüksek boyutta olduğu fakat bu farkındalı̆̆ın internet kullanım düzeylerinde herhangi bir azalış ya da vazgeçme eğilimlerine yeterince yansımadığı ifade edilmiștir. Ek olarak internet ve bireyler arasındaki ilişki bağının yüksek olmasının özgürlük, güvenlik ve gizlilik gibi kavramların önem seviyesini düşük düzeyde bıraktığını da söylemiştir. Bir başka çalışmada ise online alışveriş sitesi tercihinde etkili olan faktörler ele alınmıștır. Güvenilirlik ve gizlilik kriter grubunda kredi kartı bilgilerinin kullanılması, alışveriş sıklı̆̆ının kaydedilmesi ve alıșveriș örüntüsünün ortaya çıkmasından dolayı en önemli faktörün kişisel bilgi gizliliği olduğu görülmüştür. Ayrıca katılımcıların veri aktarma, paylaşma noktasındaki endişelerinin de oldukça yüksek olduğu belirtilmiştir (Cavlak, 2012). E-ticaret sitelerinde müşteri algılarının müşteri memnuniyetine etkisinin araştırıldı ̆̆ı bir diğer çalışmada; gizlilik, güvenlik, müșteri hizmetleri ve cevap verme yeteneği birer faktör olarak alınmıștır. Güvenlik algısının belirleyici rol oynadığını ifade eden araştırma aynı zamanda online alışveriş sitelerinin, kişisel verilerin korunması konusundaki mevzuata uygun hareket etmesi konusuna da dikkat çekmiştir. Güvenlik ve gizliliğin stratejik bir faktörden ziyade müşteri memnuniyeti için temel bir gereklilik olduğunu ifade etmiştir (Ateş, 2017).

Kişisel verilerin güvenliğine yönelik sınırlama ve düzenlemeler internet üzerinden alışveriş yapılmasına olanak sağlayan e-ticaret sitelerine de uygulanmaktadır. Müşterilerin e-posta, adres, telefon, kredi kartı gibi bilgilerini alan e-ticaret siteleri bu bilgileri saklama, işleme, aktarım yapma gibi faaliyetlerde bulunmaktadır (Ersoy, 2016). E-ticaret ile ilgili çıarılan ilk yasanın 2003 yılındaki mesafeli sözleşmeler yasası olduğu bilinmektedir. Bu yasa ile birlikte çeşitli düzenlemeler yapılmış ve hala daha iyileștirmeler devam etmektedir (Özcan, Ata, Avarkan, Yıldırım, \& Yıldırım, 2017). Elektronik ticaretin düzenlenmesi hakkında yürürlüğe giren kanunla bilirlikte e-ticaret şirketlerinin gizlilik kuralları, veri ișleme ve saklama durumları ile ilgili bilgi verme yükümlülükleri belirlenmiştir. Ayrıca kanun onay alınmaksızın bir bilgi paylaşımı ve ticari ileti gönderme durumuna yönelik gerekli cezai yaptırımları da düzenlemiştir (T.C. Cumhurbaşkanlığı 
Mevzuat Bilgi Sistemi, 2014). Kişisel verilerin kullanım amaçları, saklanma durumları ve silinme süreleri ile ilgili bilgiler genellikle gizlilik sözleşmelerinde verilmektedir. E-ticaret sitelerinde bu durum üyelik oluşturma adımında da görülebilmektedir. Bu yüzden "Üyelik ve Gizlilik Sözleşmesi" olarak bütünleşik bir yapıda da sunulmaktadır.

Gizlilik sözleşmesi, tarafların birbirlerine açıkladıkları bilgilerin gizli kalması hususunda anlaştıkları bir sözleşmedir. Sözleşmeler yapılan işi riske atma ve edinilen bilginin haksız rekabete yol açarak kötüye kullanımını engelleme amacı taşımaktadır (Blackshaw, 2011). Gizlilik sözleşmelerinin yapısı genellikle tarafların tanımlanması, tarafların hak ve borçları, sözleşme feshi ve yürürlük gibi kısımlardan oluşmaktadır. Karşılıklı herhangi bir mağduriyetin yaşanmaması ve sorumlulukların bilinmesi açısından tarafların hak ve borçları kısmı oldukça önemlidir (Şenbaş, 2013). Eticaret şirketlerinin sorumlulukları ele alındığında eticaretteki suistimal davranıșının sadece tüketici güvenini olumsuz etkilemediğini, aynı zamanda toplumun ekonomik kalkınmasında da sorunlara yol açtığı görülmektedir. Bu nedenle, pazarlamanın ilgili taraflar arasında yasal olarak yürütülmesi için e ticaret sağlayan tarafın kullanıcı ile sözleşme yapma sorumluluğu bulunmaktadır (Ginting \& Azwar, 2020).

E-ticaret ve veri gizliliği konusu da bilimsel çalışmalar da ele alınmaya çalışılmıştır. E- ticarette veri gizliliğine yönelik yapılan çalışmalarda e-ticaret sitelerinde alışveriş yapan bireylerin veri gizliliği konusundaki endişelerinin gizlilik politikaları ve sözleşmeleri ile azaltılabileceği anlaşılmaktadır (Bhat, Prasad, Sinha, Sagorkar, \& Fernandes, 2018). Çetintaş (2019) sosyal medyadaki pazarlama faaliyetlerinin artması sonucunda veri tabanındaki kişisel verilerin kullanıcıya etkilerini araştırmıştır. Çalışmada cinsiyet ve eğitim durumuna göre kişisel verilerin korunmasına ilişkin kullanıcı bilgi seviyeleri arasında bir farklılık bulunmazken yaş değişkeni açısından farklılık olduğu görülmüștür. 50 yaş ve üzerindeki katılımcıların bilgi düzeylerinin diğer katılımclara oranla daha yüksek seviyede olduğunu ifade etmiştir. Karlıdağ ve Bulut (2015) tarafından yapılan çalışmada ise e-ticarette tüketici gizliliğinin korunması ile ilgili Türkiye'de en çok tercih edilen 50 adet e-ticaret sitesinin gizlilik sözleşmelerini incelemiş ve içerik analizi uygulanmıştır. Örneklemde yer alan e-ticaret siteleri gizlilik sözleşmelerinde kullanıcı bilgisi dışında üçüncü kişilerle bir veri paylaşımı yapmayacaklarını söyleseler de bilgi koruma noktasında herhangi bir sorumluluk almadıkları görülmüştür. Bazı işletmeler ise kullanıcı bilgilerini işletmeye ait varlık olarak nitelendirdikleri ve kendi çıkarları doğrultusunda kullandıklarını ifade etmiştir. Konu ile ilgili yapılan bir başka çalıșmada, forum kullanıcılarının yapmış oldukları elektronik alışverişte siteye karşı güven derecesi araştırılmış ve yaş, cinsiyet, eğitim durumu gibi değişkenler baz alınmıștır. Sonuç olarak eğitim ve yaş değișkenlerinin siteyi güvenli bulma durumu arasında anlamlı bir ilişki olduğu ifade edilmiştir. Ayrıca Y kuşağında bulunan katılımcıların internetten alışveriş yapma sıklığının daha fazla olduğu da görülmüştür (Özcan ve diğerleri, 2017).

Gizlilik sözleşmeleri ve e-ticaret alanında yapılan çalışmalar değerlendirildiğinde genellikle anket, gözlem veya görüșme tekniği ile veri toplandığı fakat deneysel çalışmaların oldukça az olduğu görülmektedir. Çağltay (2011)’a göre deneysel çalışmalar kullanıcıların, arayüzün, görevlerin ve uygulama ortamının tamamen gerçeklik olgusu içerisinde gerçekleşmesini sağlamaktadır.

Çalışmanın amacı 6698 sayılı kanun ve e-ticaret hakkında yapılan yasal düzenlemeler için de büyük öneme sahip e-ticaret süreçlerinde de yer alan gizlilik sözleşmelerinin kullanıcılar tarafından ne ölçüde dikkate aldığını ortaya koymaktır. Çalışma kapsamında aşağıdaki araştırma sorularına cevap aranmiştır.

- E-ticaret sitesinde bulunan gizlilik sözleşmesini okuma ve onaylama sürecinde odaklanılan bölümler, ifadeler, odaklanma seviyeleri bakımından;

- Kadın ve erkek katılımcılar arasında fark var midır?

○ X, Y, Z kuşakları arasında fark var mıdır?

○ Lise, Lisans ve Lisansüstü eğitim seviyeleri arasında fark var mıdır?

- Katılımcıların gizlilik sözleşmesinin bölümlerine odaklanmaları açısından bir farklılık var mıdır?

$\mathrm{Bu}$ soruların cevaplanması amaciyla kullanıcıların sözleşme metinlerindeki bölümlere/ifadelere odaklanma ve gezinme analizlerini yapabilmek için göz takip cihazı ile göz hareketleri verisi toplanmıştır. Kuşak, cinsiyet ve eğitim seviyelerinin değişken olarak ele alınan bu çalışma toplamda 16 katılımcı ile gerçekleştirilmiştir.

\section{2 | YÖNTEM}

Çalışma kapsamında bir e-ticaret sitesi belirlenmiş ve söz konusu site yetkilileri ile görüşülerek gerekli izinler alınmıştır. Sitenin belirlenme sürecinde bu çalışma kapsamındaki örneklem grubuna hizmet etmesi, geniş ürün yelpazesine sahip olması ve deneyimli bir sayfa olmasına dikkat edilmiş, alternatifler arasından gerekli izinlerin alınabildiği web sayfası arayüz olarak tercih edilmiștir. Örneklem grubunun seçimi seçkisiz olmayan örnekleme türlerinden amaçsal örnekleme sınıfında bulunan maksimum çeşitlilik örnekleme yöntemi ile sağlanmıştır. Maksimum çeşitlilik örnekleme 
yöntemi; araştırmanın amacıyla tutarlı olarak belirlenen farklı durumlar arasındaki ortak ya da ayrılan yönlerin ve örüntülerin ortaya çıkarılmasını hedeflemektedir (Büyüköztürk, Kılıç Çakmak, Akgün, Karadeniz, \& Demirel, 2014). Araștırma örneklemini farklı cinsiyet, eğitim seviyeleri ve kuşak gruplarından olmak üzere 16 katılımcı oluşturmaktadır. Erer (2020)'de ele alınan yıl bazlı kuşak sınıflandırılması dikkate alınarak X, Y, Z kuşakları belirlenmiştir. Katılımcıların demografik dağılım bilgileri Tablo 1'de sunulmuştur.

Tablo 1. Katılımclların Demografik Dağılım Bilgileri

\begin{tabular}{|c|c|c|c|c|c|c|c|c|c|c|}
\hline & \multicolumn{3}{|c|}{$\mathrm{X}$} & \multicolumn{3}{|c|}{$\mathrm{Y}$} & \multicolumn{3}{|c|}{ Z } & \\
\hline & $\stackrel{\mathscr{心}}{\exists}$ & 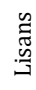 & נִּ: & $\stackrel{\mathscr{.}}{\Xi}$ & 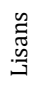 & גִּ: & $\stackrel{\mathscr{\Xi}}{\exists}$ & 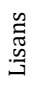 & נִ & $\begin{array}{l}\text { ్ㅐ } \\
\text { 영 }\end{array}$ \\
\hline Erkek & 1 & 1 & 1 & 1 & 1 & 1 & 1 & 1 & 1 & 8 \\
\hline Kadın & 1 & 1 & 1 & 1 & 1 & 1 & 1 & 1 & 1 & 8 \\
\hline Toplam & 2 & 2 & 2 & 2 & 2 & 2 & 2 & 2 & 2 & 16 \\
\hline
\end{tabular}

Tablo 1'de görüldüğü üzere sekiz erkek sekiz kadın olmak üzere toplamda 16 katılımcıdan veri alınmıştır. 1980 öncesi doğumlu olan X kuşağı ve 1980-2000 yılları arasında doğmuş olan Y kuşağı katılımcılardan her eğitim seviyesinde eşit ve ikişer kişi katılım sağlarken 2000 ve sonrası doğan Z kuşağı katılımclarından sadece Lise ve Lisans düzeyinde katılımclar örneklem grubuna dahil edilmiştir. Bunun nedeni $\mathrm{Z}$ kuşağında bulunan bireylerin yaş itibari ile en fazla lisans seviyesinde eğitim alabilmeleridir. $\mathrm{Bu}$ durum göz önünde bulundurularak 18 yaş altında bulunan katılımcılardan veli izin beyanları alınmıştır. Ayrıca çalışma kapsamında tüm katılımcılardan gönüllülük beyanı ve etik kurulu izin belgesi de alınmıştır. Katılımcılar Şekil 1'de gösterilen deney süreci kapsamında görevlerini gerçekleştirmişlerdir.

\section{Şekil 1. Deney Süreci}

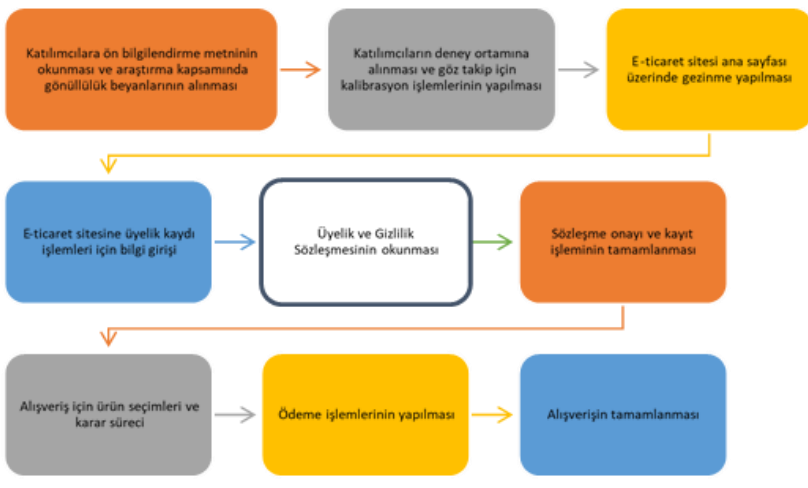

Şekil 1'de de görüldüğü üzere katılımcılar gerçek bir alışveriș süreci içerisinde görevlerini gerçekleştirmişlerdir. $\mathrm{Bu}$ çalışma kapsamında araştırılan üyelik ve gizlilik sözleşmelerinin okunması ve onay işlemleri de bu sürecin bir parçası olmuştur. "Üyelik ve Gizlilik Sözleşme" sinin okunmasında; taraflar, sözleşmenin konusu, tarafların hak ve yükümlülükleri, sözleşmenin feshi, ihtilafların hali, yürürlük bileşenleri dikkate alınmıştır. Sözleşme unsurlarında, taraflar ve sözleşmenin konusu başlıkları sözleşme metninin giriş kısmı, tarafların hak ve yükümlülükleri gelişme kısmı diğer bașlıklar ise sonuç kısmı olarak ele alınmaktadır. Sözleşme metni göz hareketleri odağında incelenirken bu bölümler üzerinden değerlendirme yapılmıştır.

Veri toplama yöntemi olarak kullanılabilirlik test yöntemlerinden deneysel yaklaşım (kullanıcı testleri) yöntemi kullanılmıştır. Deneysel yaklaşımda söz konusu deney ortamında veriler göz izleme cihazı kullanılarak elde edilmiştir. Göz izleme cihazı, kullanıcıların nereye, ne kadar süreyle dikkat ettikleri, hangi bilgiyi göz ardı ettikleri gibi konular hakkında veri sunmaktadır (Çağıltay, 2011). Göz izleme cihazının kullanımı; kullanıcıların gizlilik sözleşmesini okuma ve onaylama süreçlerindeki göz hareketlerinin kaydedilmesi ve gizlilik sözleşmelerinin kullanıcılar tarafindan ne derecede dikkate alındığını söylemektedir. Bu yöntem kullanıcı gözünden gizlilik sözleşmelerinin nasıl göründügünü öğrenme firsatı sunarken tarafsız verilerin alınmasını sağlaması açısından da önemlidir.

Ayrıca yapılan deneysel çalışmalara bakıldığında göz takip cihazları ile yapılan çalışmaların sayısı oldukça fazladır. Göz takip cihazı özellikle nöropazarlama alanındaki araştırmalarda EEG, deri iletkenliği, FMRI gibi cihazlarla birlikte kullanılmaktadır. Göz takip cihazı; görseller, kamu spotları reklamlar ve metin analizlerinde nicel analizlere göre daha az örneklem sayısı ile yapılabilmesi araştırmacılara avantaj sağlamaktadır (Yücel \& Coşkun, 2018). Nielsen (1993) deneysel yaklaşım ile yapılan çalışmalarda en az beş kişi olması araştırma sorularının çözümlenmesinde \%75 başarı sağladığını ifade etmektedir (Çağıltay, 2011). Kullanıcıların site üzerinde gerçekleştirdikleri görev süresi boyunca göz hareketlerini takip ederek; odaklanılan noktalar, odaklanma süreleri ve göz gezinim yörüngesi gibi bilgilerin alınması SMI Red250 Eye Tracking cihazı ile sağlanmıştır. Çalışma kapsamında araştırmacıların rolü; deney ortamını hazırlamak, katılımcıyı deney süreci hakkında bilgilendirmek gerekli kalibrasyon işlemlerini gerçekleştirmek, verileri toplamak ve analizlerini yaparak raporlamaktır.

Toplanan verilerin analizi BeGaze 3.7 yazılımı kullanılarak yapılmıştır. Analiz aşamasında katılımcıların göz hareketleri incelenmiş ve sözleşme metni üzerindeki odaklanmaları; odaklanma haritalarıyla, gezinme yörüngeleri; tarama yolu haritalarıyla, odaklanma süreleri ve noktaları ise sıcaklık haritalarıyla yorumlanmıştır. Veri analizleri 
yapılırken katılımcıların cinsiyet, eğitim ve kuşak seviyeleri olmak üzere üç ayrı grup halinde incelenmiş ve tüm katılımcıların bir arada olduğu genel analiz işlemi de yapılmıştır. Yapılan alanyazın taramasında güncel kaynaklara ulaşılmış olması ve uygulanan veri toplama yönteminde göz takip cihazı kalibrasyon aşamasında katılımcıların sağ ve sol gözlerindeki hareket sapmalarının 0,5 ten az olması da çalışmanın geçerlilik ve güvenilirlik açısından önemini oluşturmaktadır. Çalışma gerçek bir alışveriş sürecinde yapılmış, katılımcıların bir göz izleme cihazı ile test edildiklerini bilmeleri rağmen istem dışı odaklanma veya odaklanamama durumlarının olmadığı varsayılmıștır.

\section{3 | BULGULAR}

Katılımcıların göz hareketlerine ait toplanan verilerin analiz sonucunda öncelikle katılımcı grup farklılıkları gözetilmeden elde edilen bulgular sunulacaktır. 16 katılımcının tamamına ait odaklanma süreleri, odaklanma seviyeleri ve gezinme yörüngelerinin olduğu bulgulara yer verilecektir. Sonrasında grup özelliklerinin dikkate alındığı cinsiyet, eğitim ve kuşak grupları için analiz sonucunda nispeten görsel olarak daha anlamlı sonuçlar elde edilen bulgulara yer verilecektir.

İlk olarak bütün katılımcıların gizlilik ve üyelik sözleşmesini onaylama sürecinde odaklanma noktaları; Isı ve odaklanma haritaları ile analiz edilmiş ve 16 katılımcıya ait bulgular Şekil 2'de sunulmuştur.

\section{Şekil 2. Katılımcıların Gizlilik Sözleşmesine Odaklanma Genel Analizi}

Şekil 2.a. Odaklanma Haritası (Focus Map)

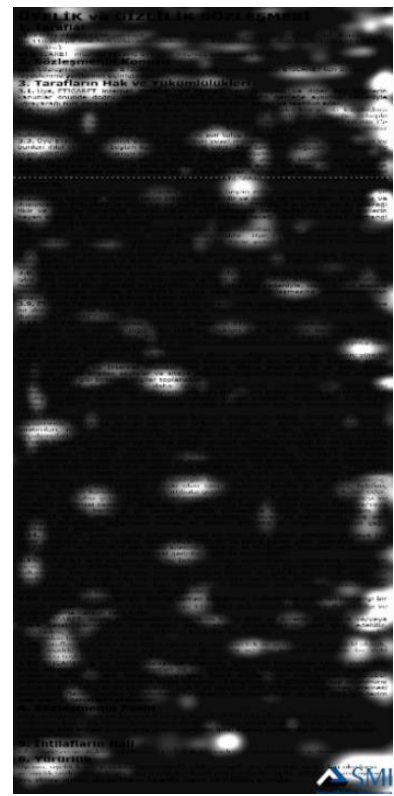

Şekil 2.b. Isı Haritası (Heat Map)

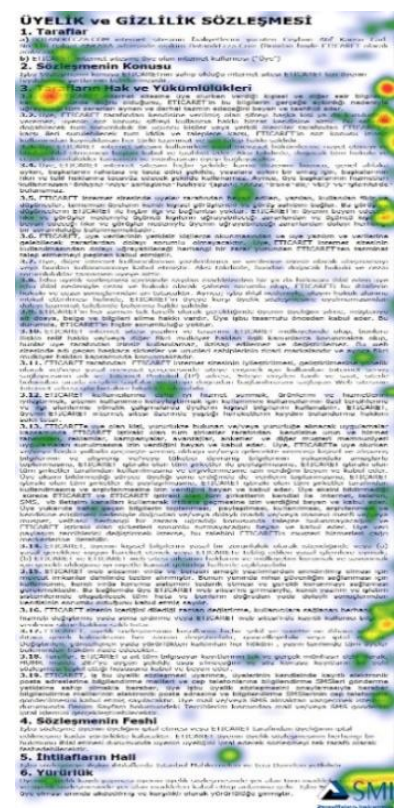

Şekil 2'de katılımcı özellikleri göz ardı edilerek tüm katılımcılara ait genel odaklanma noktaları görülmektedir. Odaklanma bölümleri odaklanma haritasında (focus-map) netleştirilerek verilirken Isı haritasında ise (heat-map) katılımcların odaklanma seviyeleri renklendirilerek gösterilmiştir. Odaklanma seviyesi yüksek olan bölümler kırmızı renkte verilmiş olup en az odaklanma seviyesi olan bölümler ise mavi renkte sunulmuştur. Sözleşme metni onaylama sürecinde bütün katılımcıların odaklanma süreleri ve göz hareket yörüngelerinin bulunduğu analizler Şekil 3' te sunulmuştur.

Şekil 3.a 'da bulunan haritalamada katılımcıların sözleşme metninde hangi bölümlere ne kadar süreyle odaklandıkları görülmektedir. Aynı zamanda odaklanma süresi yüksek olan noktalar renklendirilerek sunulmuştur. Örneğin, katılımcıların 535,8 milisaniye süreyle en çok odaklandığı bölge kırmızı renkle gösterilirken 4.2 milisaniye süreyle en az odaklanılan nokta mavi renkle gösterilmiştir. Diğer taraftan katılımcıların gezinme yörüngesi ve göz sıçramaları Şekil 3.b' de sunulmuştur. Katılımcılar sözleşme metnini okurken giriş ve sonuç bölümlerine daha çok odaklanmış ve göz hareketleri sol-sağ-aşağı yörüngesini izlemiștir.

Şekil 3. Katılımcıların Gizlilik Sözleşmelerine Odaklanma Süreleri ve Göz Hareket Yörüngeleri

Şekil 3.a. Odaklanma Süreleri Şekil 3. b. Göz Hareket Yörüngeleri
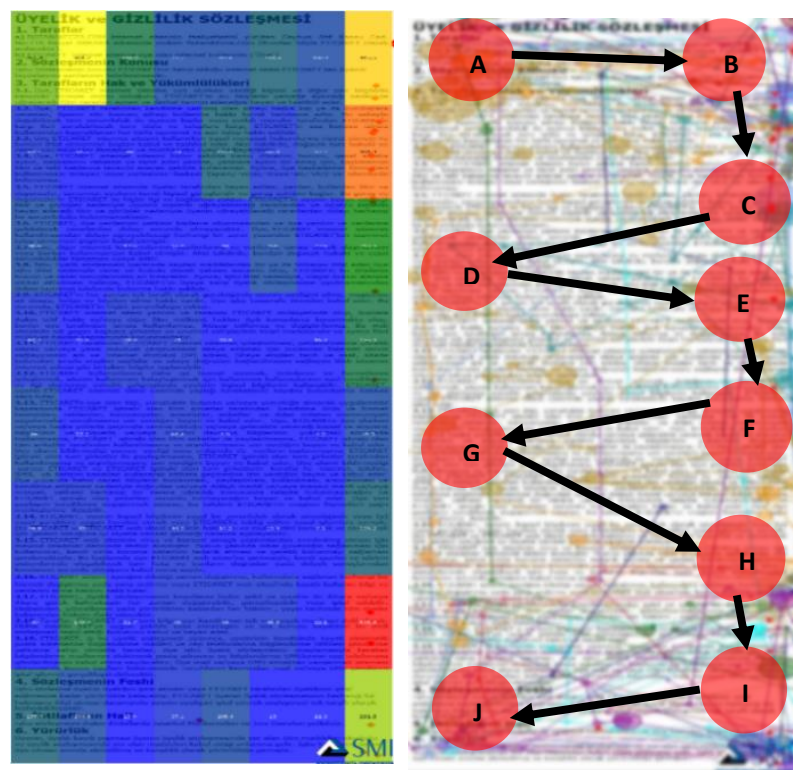

Cinsiyet farklılıkları göz önüne alındığında kadın ve erkek katılımcılara ait gizlilik ve üyelik sözleşmesi odaklanma değerlendirmesi Şekil 4' te sunulmuştur. Şekil 4'e bakıldığında katılımcıların gizlilik ve üyelik sözleșmesini onaylama sürecinde kadın katılımcılar satır sonlarına odaklanırken erkek katılımcılar nispeten metnin geneline odaklanmışlardır. Kadın ve erkek katılımcıların sözleşme metninin ilk ve son kısımlarına daha çok odaklandığı da görülmektedir. Eğitim durumları ele alınarak yapılan analiz 
sonucunda Lise, Lisans ve Lisansüstü eğitim seviyesine sahip katılımcıların sözleşme metni odaklanma değerlendirmesi Şekil 5'te yer almaktadır. Gizlilik ve üyelik sözleşmesini onaylama sürecinde lisans eğitim seviyesindeki katılımcılar diğer eğitim seviyelerine göre sözleşmenin geneline ve özellikle tarafların yükümlülükleri olan orta bölümüne daha çok odaklandıkları görülmektedir. Lise eğitim grubundaki katılımcıların ise sözleşme metninin geneline odaklanma süre ve seviyelerinin daha düşük olduğu anlaşılmaktadır.
Kuşak farklılıklarına yönelik yapılan analiz sonucunda X, Y ve Z kuşaklarına ait bulgular Şekil 6'da sunulmuştur.

Kuşaklar arasında gizlilik ve üyelik sözleşmesini onaylama sürecinde odaklanma noktalarına yönelik bir farklılık olduğu görülmektedir. Kuşaklar arasında metnin geneline odaklanma gösteren $\mathrm{Z}$ kuşağ olurken X kușağı tarafların yükümlülüklerine yok denecek kadar az bir odaklanma seviyesi göstermiştir.

\section{Şekil 4. Kadın ve Erkek Katılımclların Gizlilik Sözleşmesine Odaklanma Analizi}

KADIN KATILIMCILAR

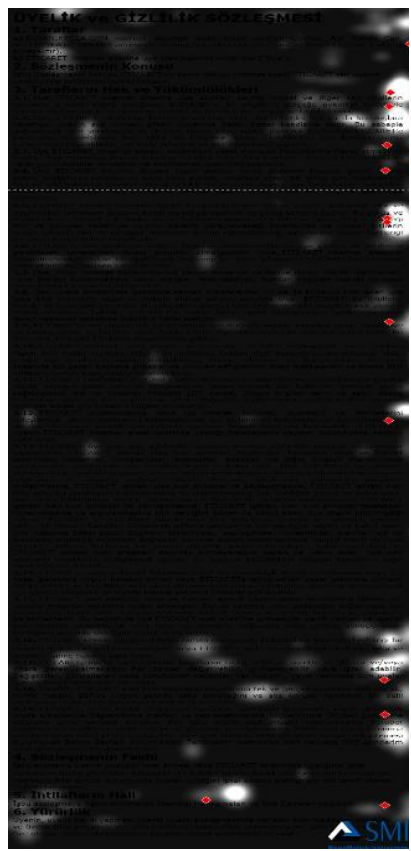

ERKEK KATILIMCILAR

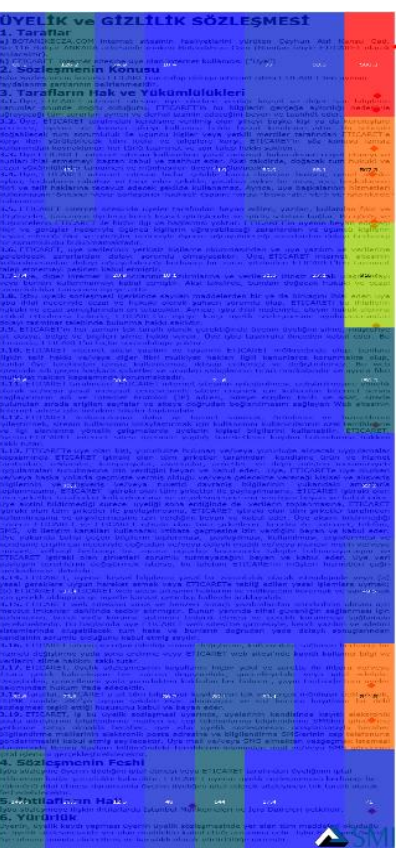

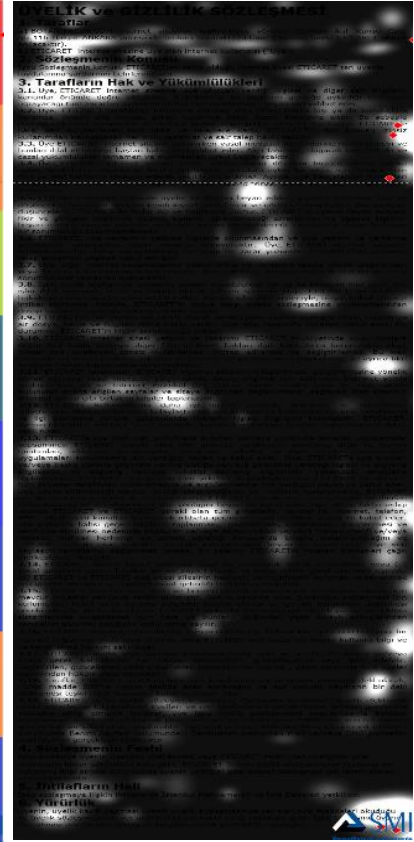

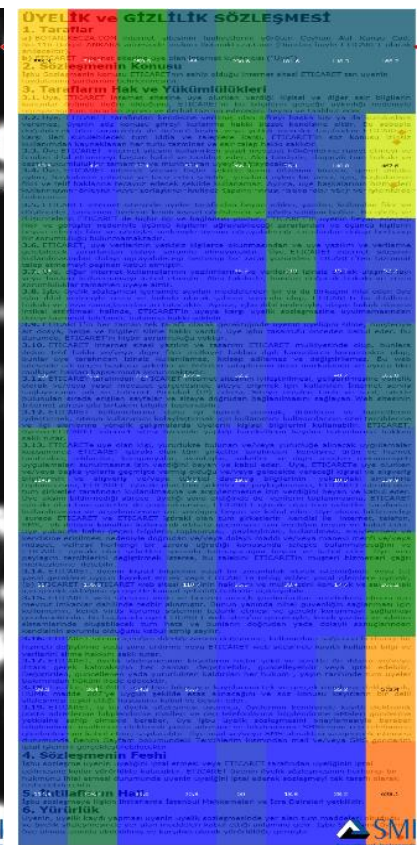

Şekil 5. Lise, Lisans ve Lisansüstü Eğitim Seviyesine Sahip Katılımclların Gizlilik Sözleşmesine Odaklanma Analizi

LISE

LISANS

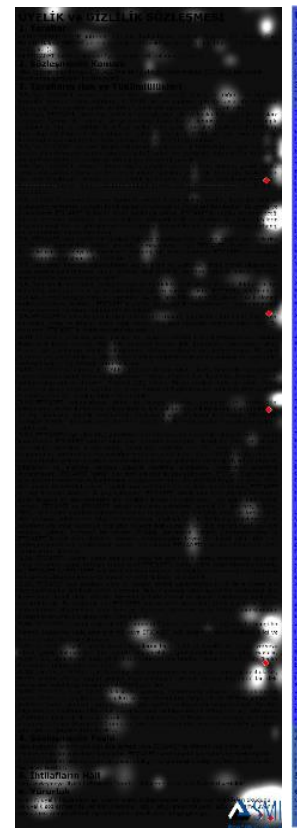

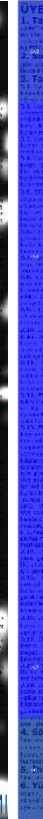

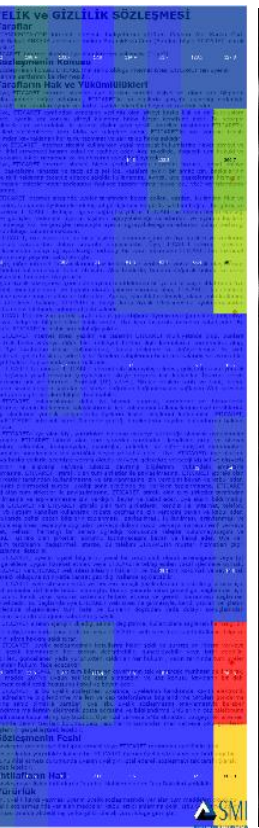

LiSANSÜSTÜ

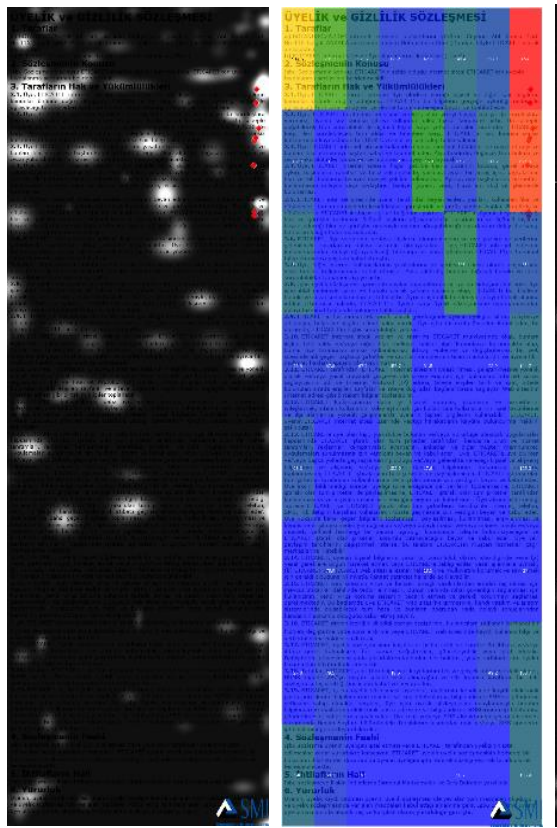

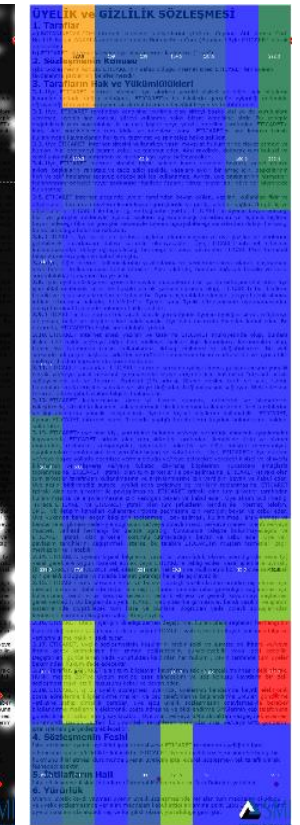


X KUŞAĞI
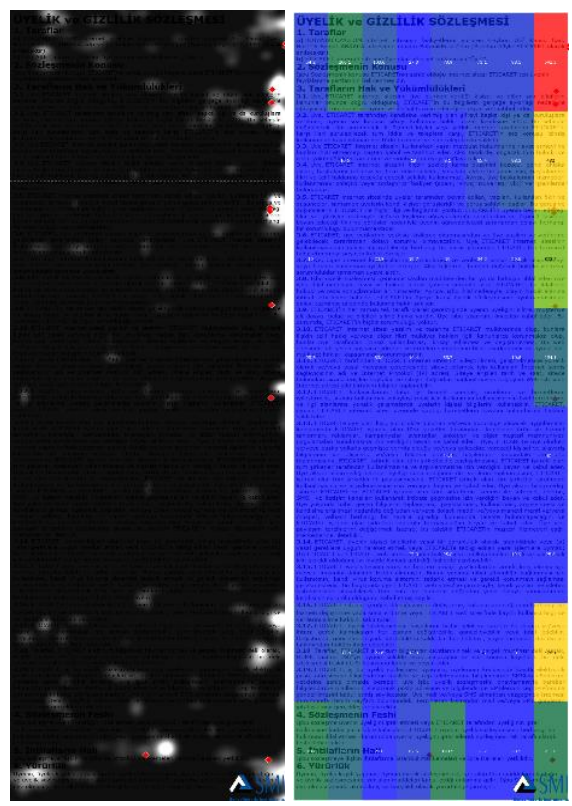

Y KUŞAĞI

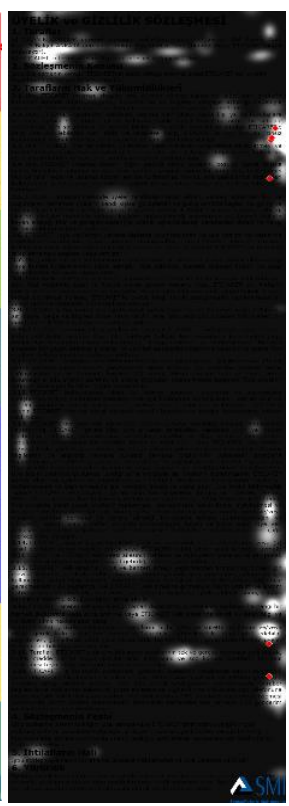

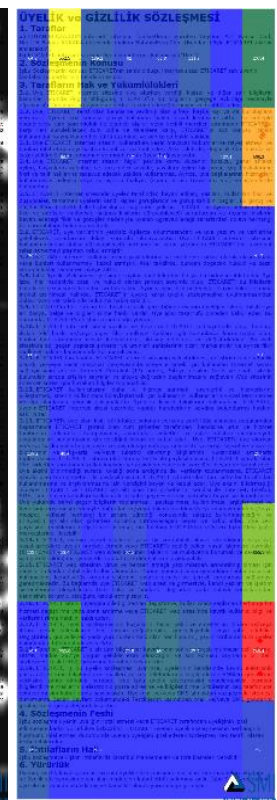

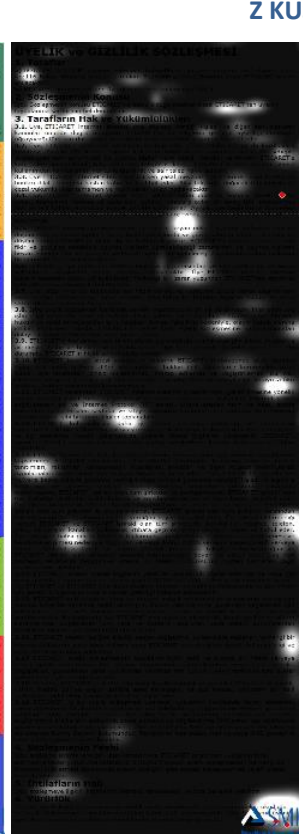

Z KUŞAĞI

\section{4 | TARTIŞMA VE SONUÇ}

E-ticaret sitelerinde bulunan gizlilik sözleșmelerine kullanıcıların odaklanma durumları, odaklandıkları bolümler ve odaklanma seviyelerinin incelendiği bu çalışma eğitim, kuşak ve cinsiyet değişkenlikleri ele alınarak yürütülmüştür. $\mathrm{Bu}$ deneysel çalışma 16 katılımcının gizlilik sözleşmesi metnini okuma sürecinde göz hareketleri değerlendirilerek elde edilen verilerin analiz edilmesiyle tamamlanmıştır. Çalışmaya ait sonuçlar araştırma soruları kapsamında iki ana bölümde sunulacaktır. İlk olarak gizlilik sözleşmelerine katılımcıların odaklanma durumları cinsiyet, eğitim seviyesi ve kuşak değişkenleri ele alınarak bir farklılık olup olmadığı değerlendirilecektir. İkinci olarak tüm katılımcıların gizlilik sözleşmesinin bölümleri arasında odaklanma durumları belirtilecektir.

Gizlilik sözleşmelerine katılımcıların odaklanma durumları incelendiğinde kadın katılımcılar genellikle cümle sonlarına odaklanırken erkek katılımcılar metnin genelinde eşit odaklanma göstermiştir. Erkek katılımcılar sözleşme metninin taraf ve yükümlülükler bölümüne odaklanırken kadın katılımcllar bu bölüme neredeyse hiç odaklanmamışlardır. Eğitim seviyeleri açısından odaklanma durumları değerlendirildiğinde Lise ve Lisansüstü eğitim seviyesindeki katılımcılar sözleșmenin konusu ve fesihi bölümlerine ve genellikle cümle sonlarına odaklanırken Lisans eğitim seviyesindeki katılımcılar sözleşmenin orta bölümüne yani tarafların hak ve yükümlülüklerine daha çok odaklanmışlardır. Bu sonuç, forum kullanıcılarının yapmış oldukları elektronik alışverişte siteye karşı güven derecesini araştıran Özcan ve diğerleri (2017)'nin eğitim ve yaş değişkenlerinin siteyi güvenli bulma durumu arasında anlamlı bir ilişki olduğu ifadesi ile benzerlik göstermektedir. Fakat Çetintaş (2019) tarafından yapılan çalışmada cinsiyet ve eğitim durumuna göre kişisel verilerin korunmasına ilişkin kullanıcı bilgi seviyeleri arasında bir farklılık bulunmaması sonucu ile örtüşmemektedir.

Kuşaklar arasındaki odaklanma durumlarına bakıldığında X ve Y kuşağındaki katılımcılar giriș ve sonuç bölümlerine ve cümle sonlarına odaklanırken $\mathrm{Z}$ kuşağındaki katılımcılar sözleşme metninin taraflar ve yükümlülükler bölümüne daha çok odaklanmışlardır. Z kuşağı bu bölümün başlığına ve bölüm içeriğine odaklanırken diğer kuşaklar bölüm başlığına dahi odaklanma göstermemiştir. Bu sonuç Dospinescu ve Percă-Robu (2017)'nun Y kuşağ katılımcıları ile e-ticaret sayfalarını değerlendirdikleri çalışmada kullanıcıların sayfanın uç kısımlarına odaklanma durumu ile benzerlik göstermektedir. Aynı şekilde Çetintaş (2019) da çalışmasında yaş değişkeni açısından kişisel verilerin korunmasına ilişkin kullanıcı bilgi seviyeleri arasında bir farklılık olduğunu ifade etmiştir.

Bütün katılımcıların gizlilik sözleşmesine odaklanma durumu incelendiğinde genellikle "taraflarsözleşmenin konusu" başlıklarının yer aldığı ilk bölüme ve "sözleşmenin fesihi-yürürlük" başlıklarının yer aldığı son bölümlere odaklanmış oldukları fakat "tarafların hak ve yükümlülükleri" bölümüne nispeten daha az odaklandıkları 
görülmektedir. Odaklanma seviyeleri bakımından sözleşmenin en çok odaklanılan son bölümü olurken en az odaklanma sözleşme metninin tarafların yükümlülükleri ve hakları bölümünün açıllamasının olduğu orta bölüm olmuștur. Bu sonuç, Șenbaș (2013) tarafından yapılan çalışmada karşılıklı herhangi bir mağduriyetin yaşanmaması ve sorumlulukların bilinmesi açısından tarafların hak ve borçları kısmının oldukça önemli görülmesi sonucu ile farklılık göstermektedir. Sözleşme metnini okuyan katılımcllar genellikle başlıklarda geçen ifadelere açıklamalardan daha çok odaklanmışlardır. Bu sonuca paralel olarak Onursoy (2018) da okuma sürecinde başlık ve yazı boyutunun oldukça etkili olduğunu ifade etmiştir.

Katılımcıların göz hareketleri incelendiğinde en çok fakat kısa göz sıçramaları ilk ve son bölümde olurken orta bölümde az sayıda ama daha uzun göz sıçramaları görülmektedir. Göz hareket yörüngesine bakıldığında okuyucular gizlilik sözleşmesini okurken cümle başından başlayarak soldan sağa sonrasında aşağıdan sola ve tekrar sol-sağ-aşağı yörüngesini izlemişlerdir. Aynı şekilde Onursoy (2018) da katılımcların renkli ve siyah-beyaz sayfalardaki davranışlarını incelediği çalışmasındaki siyah-beyaz sayfalarda dikey bir yörünge izlenmesi sonucunu ifade etmiștir. Diğer taraftan Dospinescu ve Percă-Robu (2017)'nun web sayfalarını değerlendirdikleri çalışmalarında kullanıcı bakışları site logosu ve web sayfasının çeşitli alanları arasında ileri geri hareket sağlarken metinsel bilgilerde doğrusal bir yol izlediği ifadesiyle de paralellik göstermektedir.

Sonuç olarak katılımcıların gizlilik sözleşmelerine odaklanma seviyeleri, süreleri ve odaklandıkları bölümler ele alındığında tüm eğitim seviyelerinde, cinsiyetlerde ve kuşaklarda Kutlu ve Kahraman (2017)'ın da önerdiği gibi bireylerin veri gizliliği ve KVKK bağlamında daha çok farkında olmalarına yönelik içselleștirme durumunun artması gerektiği ve bunun için de belirli bir zaman aralığına ihtiyaç duyulduğu söylenebilir. Gizlilik sözleşmelerinin bölümlerinin daha iyi anlaşılması için başlık ve içeriğin yazı fontu ve puntolarının daha etkili bir şekilde yazılması sonucu çıkarılabilir. Kullanıcıların özellikle kendi hak ve yükümlülüklerini bilmesi ve herhangi bir mağduriyet yaşamaması için sözleşmedeki bu bölümler daha sade ve anlaşılabilir bir şekilde ifade edilebilir. Gizlilik sözleşmelerinin kullanıcılar üzerinde daha etkili olması için bütün bölümler ayrı ayrı sunulabilir ve her bölüm için ayrı bir onay alınabilir. Kanun ve düzenlemeler kapsamında daha önemli görülen ifadeler farklı yazı tipi renginde, kalın ve italik yazı tipinde sunulabilir.

Çalışmanın sonraki çalışmalara yön vermesi ve bu çalışmanın sınırlılıklarını daraltmak açısından göz hareket verilerine ek olarak EEG, nabız ölçer vb. farklı cihazlar kullanılarak farklı veri tipleri üzerinden analiz ve değerlendirmeler yapılarak tekrar edilebilir. $\mathrm{Bu}$ da veri gizliliği konusunda daha etkin faaliyetlerde bulunulması açısından yapılacak çalışmalara katkı sağlayacaktır. Gelecek araştırmalarda farklı demografik faktörler haliyle daha fazla katılımcı ile araştırmalar yapılabilir. E-ticaret sitesindeki gizlilik sözleşmeleri kapsamında yapılan değerlendirme, araștırmacılar tarafından kamu kurumlarındaki gizlilik sözleşmeleri, aydınlatma metinleri gibi beyan belgeleri ele alınarak çeşitlendirilebilir.

\section{REFERENCES}

Aslanyürek, M. (2016). İnternet ve Sosyal Medya Kullanıcılarının İnternet Güvenliği ve Çevrimiçi Gizlilik ile İlgili Kanaatleri ve Farkındalıkları. Maltepe Üniversitesi İletişim Fakültesi Dergisi, 3(1), 80-106.

Ateş, V. (2017). Online Alışveriş Sitesi Kaynaklı Müșteri Algılarının Müşteri Memnuniyetine Etkilerinin İncelenmesi. Gaziantep University Journal of Social Sciences, 16(2), 313-329.

Bhat, P., Prasad, M. H., Sinha, D., Sagorkar, M. M., \& Fernandes, S. (2018). Data Privacy in ECommerce. International Journal of Scientific Research in Computer Science, Engineering and Information Technology, 3(3), 1448-1453.

Blackshaw, I. S. (2011). "Confidentiality and NonDisclosure Agreements." Sports Marketing Agreements: Legal, Fiscal and Practical Aspects. 67-72.

Büyüköztürk, Ş., Kılıç Çakmak, E., Akgün, Ö. E., Karadeniz, S., \& Demirel, F. (2014). Bilimsel Araştırma Yöntemleri (17 b.). Ankara: Pegem Akademi.

Cavlak, E. (2012). Online Alışveriş Sitesi Tercihinde Etkili Olan Kriterlerin Belirlenmesine ve Önceliklendirilmesine Yönelik Bir Araştırma. Yüksek Lisans Tezi, İstanbul Teknik Üniversitesi , Fen Bilimleri Enstitüsü Endüstri Mühendisliği, İstanbul.

Çağlltay, K. (2011). İnsan Bilgisayar Etkileşimi: Kullanılablirlik. İnsan Bilgisayar Etkileşimi ve Kullanılabilirlik Mühendisliği: Teoriden Pratiğe (1. b., s. 81-133). içinde Ankara: ODTÜ Yayıncılık.

Çetintaş, E. (2019). Sosyal Medya Pazarlama Faaliyetlerinin Artışı ve Veri Tabanında Tutulan Kişisel Verilerin Kullanıcıya Etkileri. Yüksek Lisans Tezi, Bahçeșehir Üniversitesi, İşletme, İstanbul.

Dospinescu, O., \& Percă-Robu, A. E. (2017). The Analysis of E-Commerce Sites with Eye-Tracking Technologies. BRAIN. Broad Research in Artificial Intelligence and Neuroscience, 8(3), 85-100. 
Erer, B. (2020). Örgütsel Sessizlik Davranışının X, Y ve Z Kuşağı Açısından Değerlendirilmesi. Selçuk Üniversitesi Sosyal Bilimler Meslek Yüksekokulu Dergisi, 23(2), 577-589.

Eroğlu, Ş. (2018). Dijital Yaşamda Mahremiyet (Gizlilik) Kavramı ve Kişisel Veriler: Hacettepe Üniversitesi Bilgi ve Belge Yönetimi Bölümü Öğrencilerinin Mahremiyet ve Kișisel Veri Algılarının Analizi. Hacettepe Üniversitesi Edebiyat Fakültesi Dergisi, 35(2), 130-153.

Ersoy, E. (2016). Gizlilik, Bireysel Haklar, Kişisel Verilerin Korunması. 9-11 Subat Telekomünikasyon Kurumu Akademik Bilişim 4. Bilgi Teknolojileri Kongresi. Ekim 2020, 20 tarihinde http://docslide.net/documents/gizlilikbireysel-haklar-kisisel-verilerin-korunmasi-erenersoy-telekomuenikasyon.html adresinden alındı

Ginting, B., \& Azwar, T. K. (2020). Responsibilities of the Application Provider in the Sales. International Conference on Law, Governance and Islamic Society (s. 171-174). Atlantis Press.

Karlıdağ, S., \& Bulut, S. (2015). E-Ticarette Tüketici Gizliliğinin Korunması Üzerine Bir Araștırma. İşletme Araştırmları Dergisi, 7(4), 200-224.

Kutlu, O., \& Kahraman, S. (2017). Türkiye'de Kişisel Verilerin Korunması Politikasının Analizi. Siyaset, Ekonomi ve Yönetim Araştırmaları Dergisi, 5(4).

Nielsen, J. (1993). Usability Engineering. Cambridge MA: Academic Press.

Oğuz, S. (2018). Kişisel Verilerin Korunması Hukukunun Genel İlkeleri. Bilgi Ekonomisi ve Yönetimi Dergisi, 13(2), 121-138.
Onursoy, S. (2018). Göz Takibi Deneyimiyle Gazetede Renk Faktörü. Erciyes İletişim Dergisi, 5(3), 2838.

Özcan, S., Ata, S., Avarkan, D., Yıldırım, Ö. F., \& Yıldırım, T. (2017). E-ticarette Satın Alma Davranışı ve Forum Kullanıcıları üzerine bir araştırma. TURANSAM Uluslararası Bilimsel Hakemli Dergisi, 9(33), 309-318.

Şenbaş, P. (2013). Bilgi Teknolojileri Dış Kaynak Alımında (Outsourcing) Kişisel Verilerin Korunması ve Gizlilik Sözleşmeleri. Yüksek Lisans Tezi, İstanbul Bilgi Üniversitesi Sosyal Bilimler Enstitüsü, Bilişim ve Teknoloji Hukuku Bölümü, İstanbul.

T.C. Cumhurbaşkanlığı Mevzuat Bilgi Sistemi. (2014). Ekim 15, 2020 tarihinde Elektronik Ticaretin Düzenlenemesi Hakkında Kanun: https://www.mevzuat.gov.tr/MevzuatMetin/1.5. 6563.pdf adresinden alındı

T.C. Cumhurbaşkanlığı Mevzuat Bilgi Sistemi. (2016). Ekim 15, 2020 tarihinde Kişisel Verilerin Korunması Kanunu: https://www.mevzuat.gov.tr/mevzuat?MevzuatN $o=6698 \&$ MevzuatTur $=1 \&$ MevzuatTertip $=5$ adresinden alındı

Yücedağ, N. (2019). Kişisel Verilerin Korunması Kanunu Kapsamında Genel İlkeler. Kişisel Verileri Koruma Dergisi, 1(1), 47-63.

Yücel, A., \& Coşkun, P. (2018). Nöropazarlama Literatür İncelemesi. Fırat Üniversitesi Sosyal Bilimler Dergisi, 28(2), 157-177. 